\title{
TEORIA SPOŁECZNA HANSA JOASA JAKO PRZESŁANIE DLA WSPÓŁCZESNOŚCI
}

Michał Kaczmarczyk

Uniwersytet Gdański

Wśród współczesnych teorii społecznych, które zarazem imponują oryginalnością, jak też stanowią udaną syntezę myśli klasyków i dostarczają nietrywialnej diagnozy współczesności, z pewnością wymienić można neopragmatyzm Hansa Joasa - autora, którego twórczość częściowo znana już jest polskiemu czytelnikowi za sprawą tłumaczenia jego książki Powstawanie wartości oraz tomu Kulturowe wartości Europy, wydanego pod jego współredakcją i zawierającego jego tekst na temat cywilizacji osiowych. Prezentowane obecnie w „Stanie Rzeczy” kolejne tłumaczenie jego pracy, autorstwa Marty Bucholc, wzbogaca zasób twórczości Joasa dostępnej w języku polskim o artykuł oddający jego najnowsze zainteresowania i poglądy teoretyczne.

W niniejszym komentarzu chciałbym naświetlić twórczość prezentowanego autora w kontekście jego intelektualnych inspiracji i usytuowania na mapie stanowisk teoretycznych we współczesnej myśli niemieckiej. Joas pod pewnymi względami pozostaje bowiem jej spadkobierca, rozwijającym teorię działania i podejmującym dialog z takimi autorami, jak Max Weber, Ernst Troeltsch czy Jürgen Habermas. Jednocześnie jednak rdzeniem jego wizji teoretycznej jest interpretacja twórczości George’a Herberta Meada i meadowska idea „praktycznej intersubiektywności” (1980a).

Sam Joas określa swą teorię jako kontynuację raczej amerykańskiego pragmatyzmu niż któregoś z dominujących nurtów myśli niemieckiej, nawet jeśli znaczną część jego prac zajmują dyskusje z mniej lub bardziej znanymi klasykami niemieckimi. Wedle diagnozy Joasa jedną z bolączek nie- 
mieckiej - i szerzej: europejskiej - teorii społecznej jest właśnie zapoznanie klasycznego pragmatyzmu, w którym można odnaleźć najbardziej zadowalające przezwyciężenie paradygmatu kartezjańskiego i rozwiązanie odwiecznego dylematu jednostka-społeczeństwo. Nawet amerykańska szkoła „interakcjonizmu symbolicznego” traktowała Meada wybiórczo, niemal całkowicie pomijając wkład Charlesa Sandersa Peirce’a, Johna Deweya i Williama Jamesa do teorii społecznej. Trzeba dodać, że także centralna postać socjologii amerykańskiej czasu po drugiej wojnie światowej, czyli Talcott Parsons, nie traktował bynajmniej pragmatyzmu jako istotnego źródła opracowanej przez siebie teorii działania. Wystarczy wspomnieć, że wśród wymienionych przez niego filarów teorii socjologicznej nie znalazł się Mead ani żaden inny autor amerykański. Tymczasem wedle Joasa Parsons mógłby znaleźć w pragmatyzmie rozwiązanie ważnych problemów, które bez odpowiedzi pozostawia jego słynna ksiazzka The Structure of Social Action. Problemy te sa zreszta punktem wyjścia publikacji zawierającej systematyczny wykład teorii społecznej Joasa, zatytułowanej Die Kreativität des Handelns (1996). Joas zarysowuje w niej zręby koncepcji mówiącej, że każde działanie ma trzy wymiary: racjonalny, normatywny i kreatywny. Nie przeciwstawia zatem działania kreatywnego racjonalnemu czy normatywnemu, lecz dowodzi wielowymiarowości każdego działania.

Joas wykazuje, że zasadniczym powodem kłopotów Parsonsa, a także innych socjologów wchodzących w potyczki z teorią działania było zakładanie, że główną formą tegoż jest działanie racjonalne. Nawet jeśli niekiedy tylko poddaje się regulacji normatywnej albo nie pojawia się w czystej postaci, to jest rodzajem odchylenia od założonego modelu. Paradygmatyczny charakter ma tu typologia działań zaproponowana przez Maxa Webera, choć trzeba zaznaczyć, że ani Parsons, ani Habermas nie uniknęli podobnego zawężenia mimo chęci przezwyciężenia „utylitaryzmu” czy „teorii racjonalnego wyboru”. Można by oczywiście zapytać, w jaki sposób wąski punkt wyjścia mógł determinować dalsze kroki teoretyczne wymienionych autorów, a więc na przykład, w jaki sposób koncepcja racjonalności (jakkolwiek szeroko pojmowanej) mogła przeszkodzić Habermasowi w wypracowaniu zadowalającej całościowej teorii działania. Zgodnie z argumentacja Joasa krytykowani przezeń teoretycy mniej lub bardziej świadomie pozostali $\mathrm{w}$ ramach modelu racjonalistycznego, zachowując jego kluczowe założenie o celowości wszelkiego działania. Toteż znaczna część wywodów Joasa w Die Kreativität des Handelns poświęcona jest krytyce tak zwanego teleologicznego schematu działania, wedle którego każde działanie z samej swej istoty zmierza do celu. Tymczasem wystarczy 
wziąć pod uwagę takie codzienne aktywności, jak zasypianie, śmianie się czy różnego rodzaju zabawy, by stało się jasne, że nie mają one - ba, nie mogą mieć - ściśle określonego celu. Jeśli czymś skutkuja, to nie ze względu na świadomie wyznaczone dążenie, a raczej przypadek czy mechanizmy, z którymi się liczymy, ale nie dążąc do kontroli nad nimi. Ktoś mógłby rzecz jasna zastrzec, że przywołane działania są zaledwie marginesem naszej zasadniczej aktywności: pracy, myślenia czy odpoczynku. Joas dostrzega jednak nieteleologiczny rdzeń w kluczowych pojęciach nowożytnej myśli społecznej: marksowskiej „pracy”, która jest bardziej samorealizacja niż dążeniem do wyznaczonego celu; simmelowskim ,życiu”, które jest ze swej istoty twórcze; czy wreszcie - w „,inteligencji” i „,wyrażaniu siebie”.

Teoria kreatywności działania zdaniem Joasa wymaga dopełnienia w postaci pragmatycznej teorii jaźni, którą możemy znaleźć zarówno u Meada, jak i Deweya oraz Jamesa. Wszyscy ci autorzy podkreślali, że Ja jest raczej produktem złożonego procesu poznawczego uwarunkowanego interakcjami społecznymi niż gotowym bytem działającym w świecie. Co więcej, formowanie się Ja jest procesem, który trwa całe życie, a Ja to istota zdolna nie tylko do autokreacji, ale też autotranscendencji w szczególnych doświadczeniach każących postawić pod znakiem zapytania dotychczasową koncepcję siebie. Joas podkreśla, że owe doświadczenia mogą mieć charakter pozytywny i być podstawą nowych wartości, ale często też są negatywne i wiążą się z traumą - autor jako przykłady wymienia tu doświadczenia gwałtu czy przemocy wojennej.

W książce Powstawanie wartości (2009) Joas kreśli historię koncepcji autotranscendencji, którą w jego mniemaniu można dostrzec w ideach filozoficznych i społecznych autorów końca XIX i początku XX stulecia, takich jak Friedrich Nietzsche, Émile Durkheim, William James, Georg Simmel, John Dewey czy Max Scheler. Wymienieni autorzy mieli zwracać uwagę na różne aspekty „wstrząsających” doświadczeń wykraczania poza własne Ja, spośród których Joas podkreśla: niecodzienność, całościowość - przemożny wpływ na tożsamość Ja oraz pasywność - w doświadczeniu autotranscendencji podmiot czuje się niejako poddany oddziaływaniu zewnętrznej siły, która zarazem zdaje się go wiązać w przyszłych decyzjach, jak i afektywnie przywiązywać do siebie. Nietrudno tu dostrzec nawiązanie do durkheimowskiej koncepcji sacrum, która - jak pisze sam Joas - „sytuuje się na tym samym obszarze”, opisując tworzenie się i odtwarzanie więzi społecznej w zbiorowych doświadczeniach religijnych. Joas nie chce wszakże ograniczać doświadczenia autotranscendencji do fenomenu zbiorowego, jak czyni to Durkheim, lecz korzystając także z dorobku Jamesa, określa 
je przede wszystkim jako doświadczenia indywidualne. Postuluje przy tym fenomenologię tego typu doświadczeń, która objęłaby choćby „zakochanie i miłość, otwartość Ja w udanym dialogu lub poruszającym współczuciu, jak również euforyczne doświadczenia rozpłynięcia się w przyrodzie czy doświadczenie zbiorowej ekstazy" (Joas 2017: 432).

Wszystkie omówione dotąd koncepcje zawarte w Die Kreativität des Handelns oraz Powstawaniu wartości, a więc nieteleologiczna teoria kreatywności działania, teoria powstawania jaźni w procesach interakcji społecznych oraz teoria doświadczeń autotranscendencji, stanowią niezbywalna podstawę teorii ,świętości” przedstawionej przez Joasa w Die Macht des Heiligen [Wtadzy śnietości] (2017). Joas nawiązuje tam do Powstawania wartości, przedstawiając doświadczenia autotranscendencji i genezy wartości jako podstawę koncepcji historycznej będącej alternatywą w stosunku do Weberowskiej wizji „odczarowania świata”. Joas przedstawia krytyczny pogląd na temat szerokich kategorii socjologicznych mających na celu wyjaśnienie zmiany społecznej prowadzącej do ukształtowania się „,nowoczesności”, a więc: racjonalizacji, zróżnicowania społecznego i sekularyzacji. Pojęcia te, zamiast dostarczać empirycznego wyjaśnienia, według Joasa kreuja raczej upraszczająca i ślepa na alternatywy opowieść o nowoczesności. Propozycja samego Joasa ma mieć tę przewagę, że odwołuje się ona do szczególnego typu doświadczeń będących źródłem bardzo różniących się w swych skutkach procesów historycznych. Ich wspólnym mianownikiem, a jednocześnie uniwersalnym zjawiskiem antropologicznym jest właśnie „fakt ksztaltowania się ideału”, opisywany także w tekście prezentowanym polskiemu czytelnikowi w niniejszym numerze „Stanu Rzeczy”.

Joas podkreśla bowiem, że opisywane przez niego we wcześniejszych pracach doświadczenia autotranscendencji maja dwie charakterystyczne cechy, odpowiadające za ich społeczne znaczenie. Po pierwsze, wymagaja artykulacji, które moga się odwoływać zarówno do przeszłych doświadczeń, oczekiwań społecznych, jak i dziedzictwa kulturowego. Po drugie, artykulacje te muszą się odnosić do tego, co podmiot uważa i odczuwa jako przedmiot swych doświadczeń, tego, do czego czuje się przywiązany lub co prowadzi go do przekroczenia symbolicznych granic siebie:

Coś musi stać za tym, że jednostki lub zbiorowości wyrywane sa poza dotychczasowo ustabilizowane granice swego Ja. Niezwykłe doświadczenia stopniowej utraty siebie i oczarowania wykraczającego poza wszelką codzienność prowadzą do emocjonalnego naładowania sytuacji, w których doświadczenia takie zostały po- 
czynione. W doświadczeniach samozatraty i samoprzezwyciężenia dana jest afektywna pewność, która wypełnia elementy sytuacji przedrefleksyjną mocą wiążąca, a siła tejże wykracza poza tę, która cechuje wszelkie doświadczenie codzienne. (Joas 2017: 434)

Tak rozumiana świętość jest przypisywana czemuś zewnętrznemu w procesie artykulacji, który może jednak przybrać rozmaita postać świętość nie musi z konieczności zostać utożsamiona z dobrem, zwłaszcza że nie musi być tak doświadczana. Za Charlesem Taylorem Joas wykazuje, że proces artykulacji jest nad wyraz złożony i z reguły dodaje do doświadczenia nowe elementy. W omawianej w tym momencie książce Joasa przedstawione zostały trzy zasadnicze grupy czynników warunkujących ów proces artykulacji: instytucje, wartości i praktyki. Podział ten pochodzi z wcześniejszej publikacji Joasa - Die Sakralisierung der Person (2011), w której nakreślone zostało socjologiczne wyjaśnienie powstania idei praw człowieka, nawiązujące także do durkheimowskiej koncepcji świętości.

Kluczowy wniosek płynący z Joasowskiej teorii świętości mówi, że w historii społeczeństw mamy do czynienia z wieloma, często niewspółmiernymi i trudnymi do przewidzenia, procesami sakralizacji i desakralizacji. Utrata blasku przez odziedziczone świętości może prowadzić do utraty legitymizacji przez stare porządki społeczne, podczas gdy nowe sakralizacje moga wpływać na powstawanie nowych ruchów społecznych, sojuszy i kierunków rozwoju społecznego. Procesy sakralizacji pozostają też w związkach wzajemnej zależności z kształtowaniem się konstelacji władzy społecznej, które w ocenie Joasa postrzegać należy raczej jako procesy i relacje niż struktury zasobów. Charakterystyczny dla wielu zjawisk historycznych jest proces zbiorowej autosakralizacji, w którym dana grupa społeczna zaczyna traktować siebie jako źródło jakiejś ważnej cechy czy misji społecznej, często pod pozorami uniwersalizmu, który w mniej lub bardziej zawoalowany sposób ograniczony jest do „wybranych”, a wyklucza innych (Joas 2020a). Przykładem autosakralizacji jest przede wszystkim nacjonalizm, a nawet różne formy samowywyższenia w ramach pozornie uniwersalistycznych instytucji, takich jak Kościół katolicki. Nierzadko na wskroś partykularystyczne instytucje moga prezentować się jako nośniki uniwersalizmu - pomyślmy choćby o retoryce amerykańskiego uniwersalizmu czy Polsce jako przedmurzu chrześcijaństwa. Wszelkim tego rodzaju procesom autosakralizacji rzuca wyzwanie autentyczny uniwersalizm sakralizujący osobę ludzką jako taką, a nie określoną grupę etniczną czy polityczna. Ten właśnie rodzaj uniwersalizmu dostrzega Joas w pierwotnym 
przesłaniu chrześcijaństwa, a także w rozwoju idei praw człowieka i misji wielu nowych ruchów społecznych.

Podsumowując mój krótki wstęp do tekstu Joasa, chciałbym podkreślić, że nakreślona we Władzy świętości teoria wyróżnia się nie tylko tym, że stanowi oryginalną i krytyczną syntezę wątków obecnych u klasyków socjologii i filozofii, lecz także tym, że proponuje wiarygodną diagnozę ewolucji władzy i jasny postulat normatywny: „uniwersaliści, wierzący i niewierzący, łączcie się!”.

Bibliografia wybranych prac Hansa Joasa:

/// 1973. Die gegenwärtige Lage der soziologischen Rollentheorie, Athenäum.

/// 1980a. Praktische Intersubjektivität. Die Entwicklung des Werks von George Herbert Mead, Suhrkamp.

/// 1980b (współautor: Axel Honneth). Soziales Handeln und menschliche Natur. Anthropologische Grundlagen der Sozialwissenschaften, Campus, Studium-Reihe.

/// 1987 (współautor: Michael Bochow). Wissenschaft und Karriere, Campus.

/// 1992. Pragmatismus und Gesellschaftstheorie, Suhrkamp.

/// 1996. Die Kreativität des Handelns, Suhrkamp.

/// 2000. Kriege und Werte. Studien zur Gewaltgeschichte des 20. Jahrbunderts, Weilerswist.

/// 2004a. Braucht der Mensch Religion? Über Erfahrungen der Selbsttranszendenz, Herder.

/// 2004b (współautor: Wolfgang Knöbl). Sozialtheorie. Zwanzig einfübrende Vorlesungen, Suhrkamp.

/// 2008 (współautor: Wolfgang Knöbl). Kriegsverdrängung. Ein Problem in der Gescbichte der Sozialtheorie, Suhrkamp.

/// 2009. Powstawanie wartości, Oficyna Naukowa.

/// 2010 (współautor: Jose Casanova). Religion und die umstrittene Moderne, Kohlhammer (seria „Globale Solidarität - Schritte zu einer neuen Weltkultur", t. 19). 
/// 2011. Die Sakralität der Person. Eine neue Genealogie der Menschenrechte, Suhrkamp.

/// 2012. Glaube als Option: Zukunftsmöglichkeiten des Christentums, Herder.

/// 2014. Was ist die Achsenzeit? Eine wissenschaftliche Debatte als Diskurs über Transzenden₹, Schwabe.

/// 2015a. Die lange Nacht der Traner. Erzäblen als Weg aus der Gewalt?, Psychosozial-Verlag.

/// 2015b. Sind die Menschenrecbte westlich?, Kösel.

/// 2016. Kirche als Moralagentur?, Kösel.

/// 2017. Die Macht des Heiligen. Eine Alternative zur Geschichte von der Entrauberung, Suhrkamp.

/// 2020a. Im Bannkreis der Freiheit. Religionstheorie nach Hegel und Nietzsche, Suhrkamp.

/// 2020b. Friedensprojekt Europa?, Kösel.

/// Michał Kaczmarczyk - pracuje jako profesor uczelni na Uniwersytecie Gdańskim, gdzie kieruje Zakładem Teorii Socjologicznej i Metodologii Nauk Społecznych. W ostatnim czasie opublikował między innymi książkę Aporia wolności. Krytyka teorii społecznej (2019) wyróżnioną Nagroda im. Jana Długosza oraz Nagrodą Dziennikarzy na Poznańskich Targach Książki.

ORCID: https://orcid.org/0000-0003-0828-7272

E-mail: michal.kaczmarczyk@ug.edu.pl 